\title{
System Dynamics Model of Transit Oriented Development Implementation to Reduce Carbon Emission from Urban Transportation
}

\author{
Raulia Riski, Erma Suryani, Ulfa Emi Rahmawati, and Gustin Ayu Cahyandini \\ Department of Information Systems, Institut Teknologi Sepuluh Nopember, Surabaya \\ e-mail: erma@is.its.ac.id
}

\begin{abstract}
The biggest carbon emissions in urban areas are generated from the transportation system, including in Surabaya City where the transportation sector contributes 5.48 million tons of carbon emissions per year, or about $96 \%$ of the total air emissions there. With the cities rapid development, urban transportation systems need to be managed appropriately to avoid environment damage. The most effective way to reduce carbon emissions from the transportation system is by reducing the number of private vehicles uses. TOD is one of the solutions that can be applied, which is through the integration of mixed land development and the construction of transit mode transportation systems. TOD allows people to carry out various daily activities with close transportation distances, either using transit modes, walking, or cycling. This study aims to show the benefits of applying TOD in reducing carbon emissions from the transportation sector in Surabaya using a system dynamics model. The model produced can be used as a reference or consideration for the government and other related parties in developing strategies and policies related to the implementation of TOD. Future studies can analyze several TOD scenarios that can be carried out to reduce carbon emissions from the transportation sector in Surabaya.
\end{abstract}

Keywords-Carbon emissions, Transit Oriented Development, Urban Transportation, System Dynamics, Causal Loop Diagram.

\section{INTRODUCTION}

$\mathrm{C}$ ITIES around the world are faced with the problem of deteriorating air quality as a result of increased economic activity [1]. Of all sources of air pollution, the transportation sector is the main contributor to air pollution and the largest emitter of carbon in urban areas [2]. Surabaya is one of the largest cities in Indonesia. According to the Forest Monitoring Report of Surabaya in [2], the transportation sector in Surabaya contributes 5.48 million tons of carbon emissions per year, or about $96 \%$ of the total air emissions in Surabaya City.

Various studies have been conducted to reduce the amount of carbon emissions, therefore, there are many ways to reduce carbon emissions in urban transportation systems, one of the most effective ways is to reduce the use of private/ share motor vehicles and change to the use of mass transportation such as BRT and MRT [3]. This is appropriate to do in Surabaya because the trip characteristics in Surabaya are still very much dominated by the use of private modes, such as motorcycles (50.95\%) and private cars (1.60\%), only 5.96\% trips that use public transportation [2].

In addition to reduce the number of private/ share transportation uses, a land use management system also has
Table 1.

Boundary Adequacy of TOD System

\begin{tabular}{|c|c|c|}
\hline Type & Variable & Unit \\
\hline \multirow[t]{20}{*}{ Internal } & Urban housing development & Percent \\
\hline & Public facilities & Percent \\
\hline & Offices, business, and entertainment & Percent \\
\hline & Mix-ness of land uses & \\
\hline & Transits & Unit \\
\hline & Bicycle networks & $\mathrm{Km}$ \\
\hline & Pedestrian networks & $\mathrm{Km}$ \\
\hline & Bicycle uses & Percent \\
\hline & Pedestrian & Percent \\
\hline & Daily travel distances & Meter \\
\hline & MRT transits & Unit \\
\hline & BRT transits & Unit \\
\hline & Distance to transits & $\mathrm{Km}$ \\
\hline & Private/ shared motor vehicles uses & Percent \\
\hline & $\begin{array}{l}\text { Carbon emission from private/ shared } \\
\text { motor vehicles }\end{array}$ & $\begin{array}{c}\text { Tons/ } \\
\text { year }\end{array}$ \\
\hline & $\begin{array}{l}\text { Carbon emission from urban } \\
\text { transportation }\end{array}$ & $\begin{array}{c}\text { Tons/ } \\
\text { year }\end{array}$ \\
\hline & $\begin{array}{l}\text { Carbon emission from public motor } \\
\text { vehicles }\end{array}$ & $\begin{array}{l}\text { Tons/ } \\
\text { year }\end{array}$ \\
\hline & $\begin{array}{l}\text { Carbon emission from other motor } \\
\text { vehicles }\end{array}$ & $\begin{array}{l}\text { Tons/ } \\
\text { year }\end{array}$ \\
\hline & People change to use MRT & Percent \\
\hline & People change to use BRT & Percent \\
\hline \multirow[t]{18}{*}{ External } & Urban population & People \\
\hline & Immigration rate & Dmnl \\
\hline & Emigration rate & Dmnl \\
\hline & Birth rate & Dmnl \\
\hline & Death rate & Dmnl \\
\hline & Economic growth & Percent \\
\hline & Safety effect of using bicycle & Percent \\
\hline & Comfort effect of using bicycle & Percent \\
\hline & Safety effect of walking & Percent \\
\hline & Comfort effect of walking & Percent \\
\hline & BRT fare effect & Percent \\
\hline & Comfort effect of using BRT & Percent \\
\hline & Safety effect of using BRT & Percent \\
\hline & BRT waiting time effect & Percent \\
\hline & MRT fare effect & Percent \\
\hline & Comfort effect of using MRT & Percent \\
\hline & Safety effect of using MRT & Percent \\
\hline & MRT waiting time effect & Percent \\
\hline
\end{tabular}

good potential in ensuring a good urban environment, especially if the land use system can regulate for a better and healthier community mobility. This situation can be achieved when the spatial distribution of residential areas, workplaces, commercial centers, and other activities areas is built in a suitable combination so that it can contribute to the origindestination travel patterns in urban transportation, and ultimately will have an impact on reducing the travel distance, the energy consumption, and the pollutant emissions [4]. The results of other studies shows that the change of private vehicles uses to public transportation is influenced by 


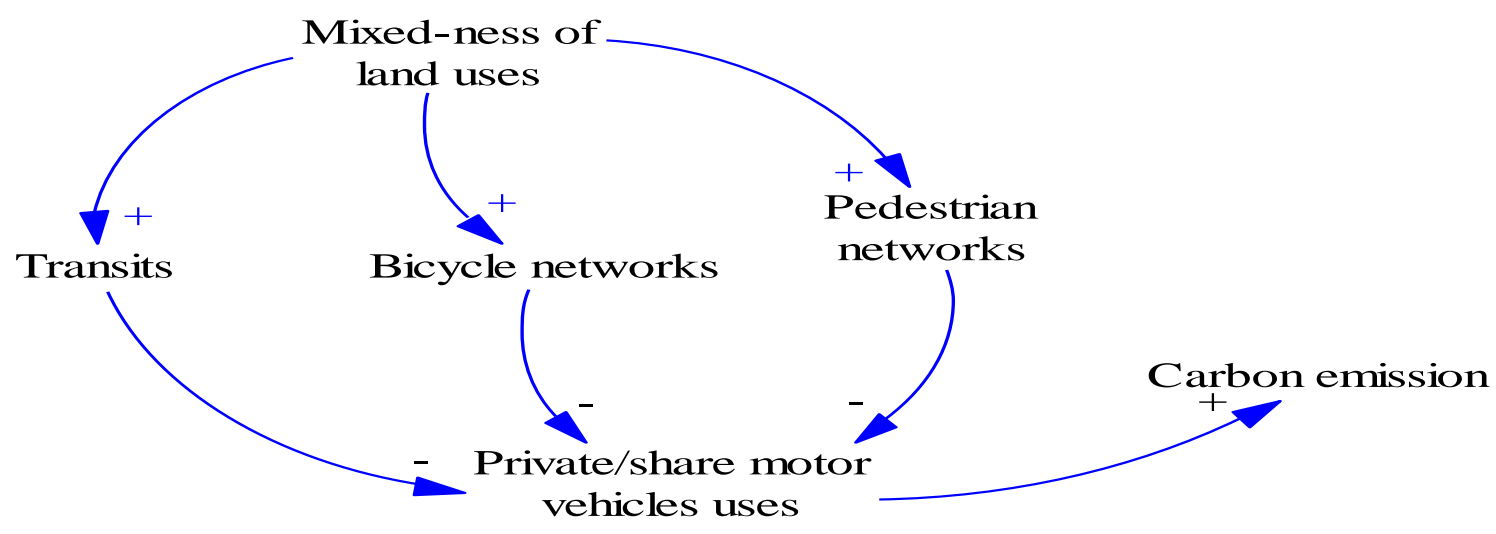

Figure 1. The Basic Pattern of the System.

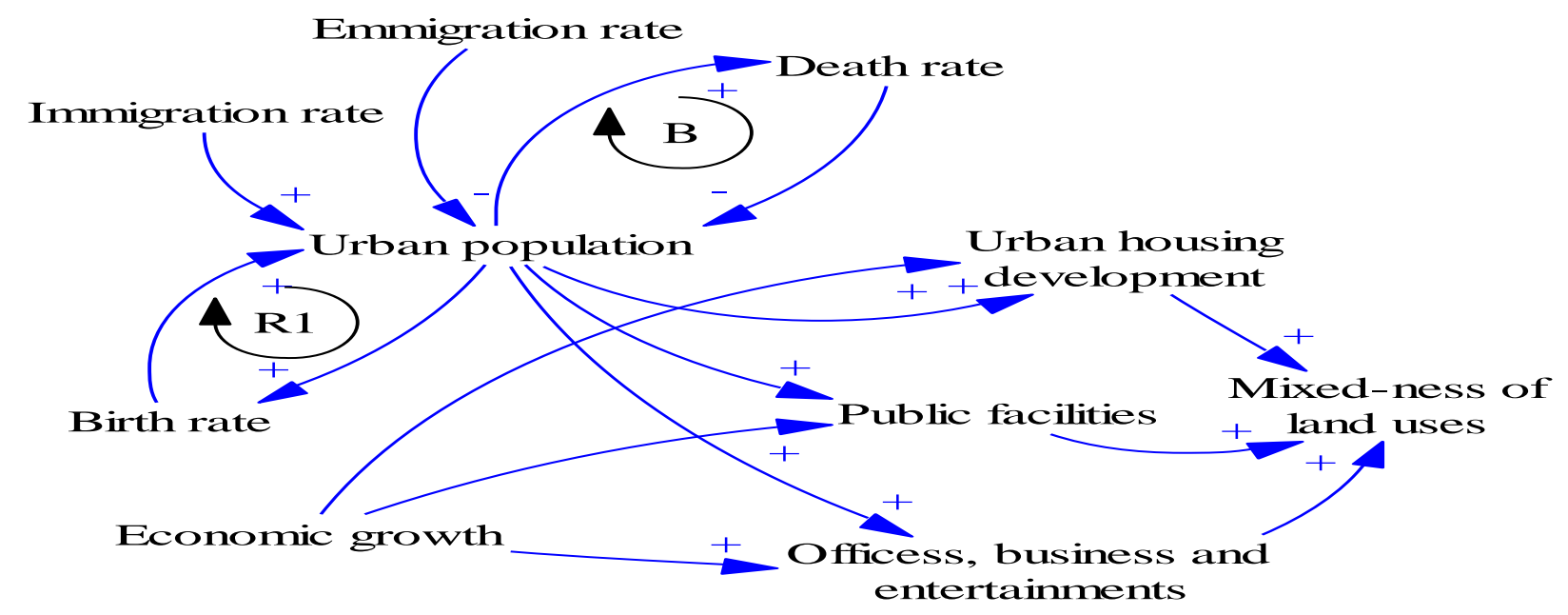

Figure 2. Mixed-ness of Land Uses Sub Model.

the design of the area around the transit location, meaning that it is necessary to integrate the area planning around the transit location with the network planning and transportation facilities that will be developed [5]. TOD covers all this discussion.

From various explanations regarding the conditions and problems above, this study uses system dynamics modeling to show and to get a better understanding of the TOD implementation to reduce carbon emissions from the transportation sector in Surabaya City. This paper is organized as follows. Section 1 explains the introduction. Section 2 explains the method used in conducting this study. Section 3 explains the results and discussion. And then the conclusion is made in Section 4.

\section{METHOD}

In this study, the SD model is used to analyze complex systems with several variables that change from time to time and determine how the system is affected by specific policy implementation [6]. Literature study also conducted to describe TOD implementation in the system.

\section{A. System and Model}

System is a collection of entities that act and interact together to achieve several goals [7]. System is categorized into two types: discrete and continuous systems [8]. Discrete system is a system where the variables change instantly at separate points in time, whereas a continuous system is a system where the variable status changes dynamically or continuously with respect to time.

Model is a representation of a real system. A model is said to be good if the model behavior could resemble the actual system on condition that it does not violate the principles of systems thinking. The development of a model is strongly influenced by the subjectivity of a person or organization so, there needs to be continuous improvements by exploring relevant information and potential [9]. The advantages of using models in research using a systems approach are: (1) it is possible to conduct cross-sectoral research with a broad scope; (2) experimentation can be done on the system without disturbing (giving certain treatment to) the system; (3) the objectives of the management and improvement activities of the system under study can be determined; and (4) the model produces can be used to predict the behavior and the system state in the future [9].

\section{B. Simulation}

Simulation is a technique of processes duplication that occurs in real systems using computer assistance based on certain assumptions, so that it can be understood scientifically [5]. Simulation can also be interpreted as a process in which a mathematical model is added to the model that has been created to support the model. Then the simulation model is carried out to determine the behavior of the system at a certain 


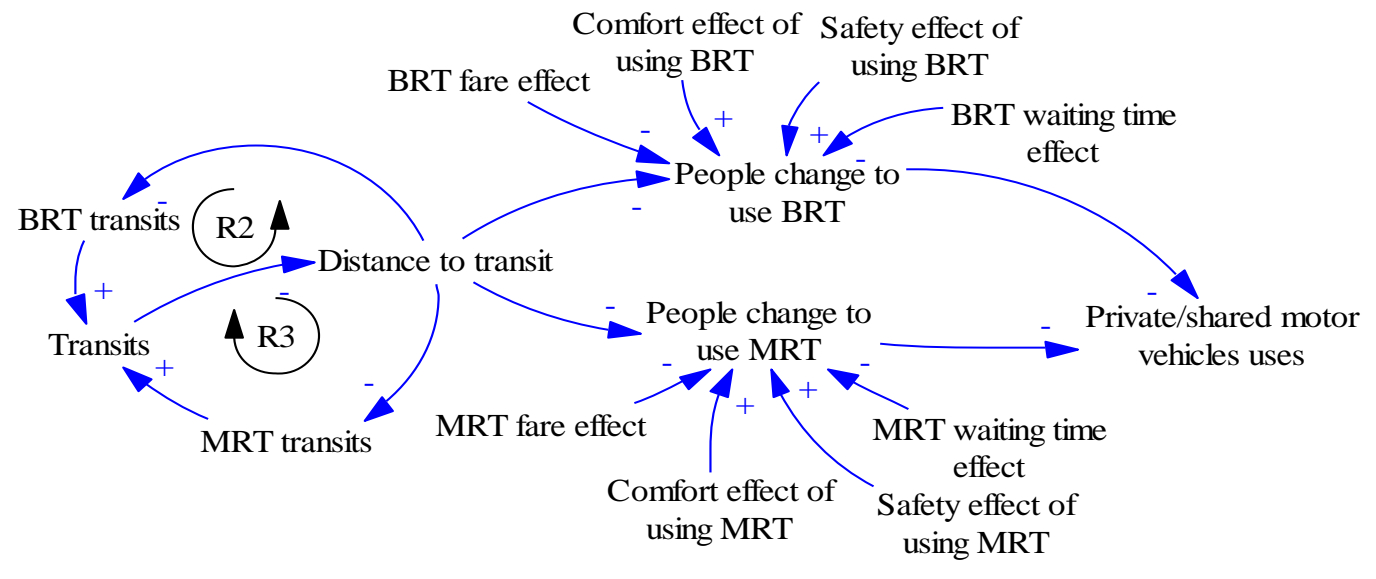

Figure 3. Transits Sub Model.

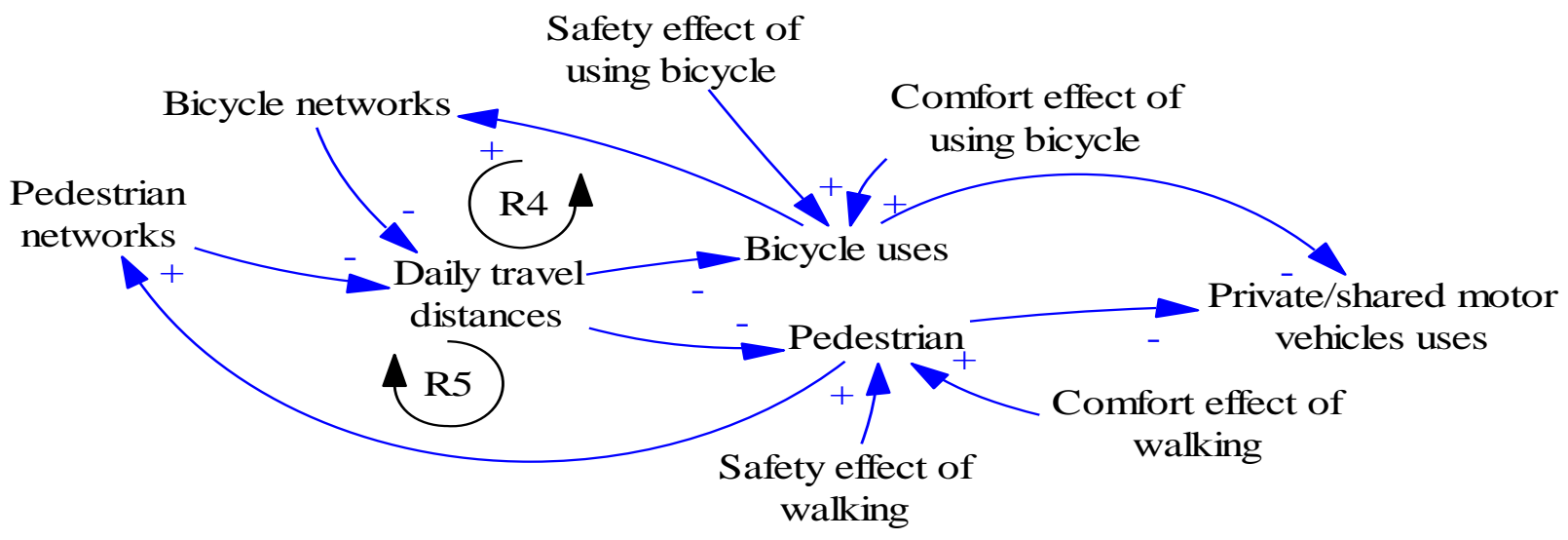

Figure 4. Bicycle Networks and Pedestrian Networks Sub Model.

time. Very effective simulation models are used for relatively complex systems for analytical solutions of these models.

\section{System Dynamics}

System dynamics (SD) was first developed by Forrester of the Massachusetts Institute of Technology (MIT) in the 1950s-1960s based on system theory, information science, organizational theory, control theory, tactical decision making, cybernetics, and military games, which methodology has been applied to fields such as government policy, medicine, the automotive industry and urban studies [3]. According to [10], Dynamic system is a method of problem analysis in which time is one of the important factors, and includes an understanding of how a system can be maintained from interference from outside the system, or how the system is made in accordance with the objectives of the modeling system to be created.

The SD model is used to study and anticipate changes over time in a complex system and can be used for systems with limited data problems, because the information used for system conceptualization and model formulation is much broader than the numerical database used in operations research and statistical modeling.

\section{D.Transit Oriented Development}

Calthorpe, an American architect, first introduced the TOD concept and defined it as a "multipurpose community within a 10-minute walk along the regional transit system and this community acts as a strategic development point with complementary work, public services, use and retail in the environment" [11]. TOD provides very efficient access to transit facilities and, when implemented in conjunction with changes in the streetscape, it will improve the walkability environment [12]. An urban environment that facilitates residents to walk more frequently and use transit modes will greatly affect the amount of carbon emissions that are formed from the urban transportation system.

TOD is closely related to the development of the area with access to transit facilities that are close, therefore the development of land with mixed-uses criteria is one of the characteristics of TOD. In connection with the characteristics of mixed land use in this TOD, the ideal mixed land use criteria are: the residential land accounts for $20 \%-60 \%$ of use, head office / commercial land accounts for $30 \%-70 \%$ of use, and public space accounts for $5 \%-15 \%$ of use [11].

TOD in favorable conditions, provides a variety of benefits including increased non-motorized access to the public transportation system, reduction of traffic pollution and energy consumption, increased public transport passengers, improved healthy lifestyles (such as walking and cycling), creating attractive destinations, shaping urban and regional polycentricity, mitigating urban sprawl, and accommodating economic growth [11].

TOD has five dimensions which can be explained as follows [13]: (1) Density, Diversity and Design are mentioned as the three most important dimensions of TOD, 


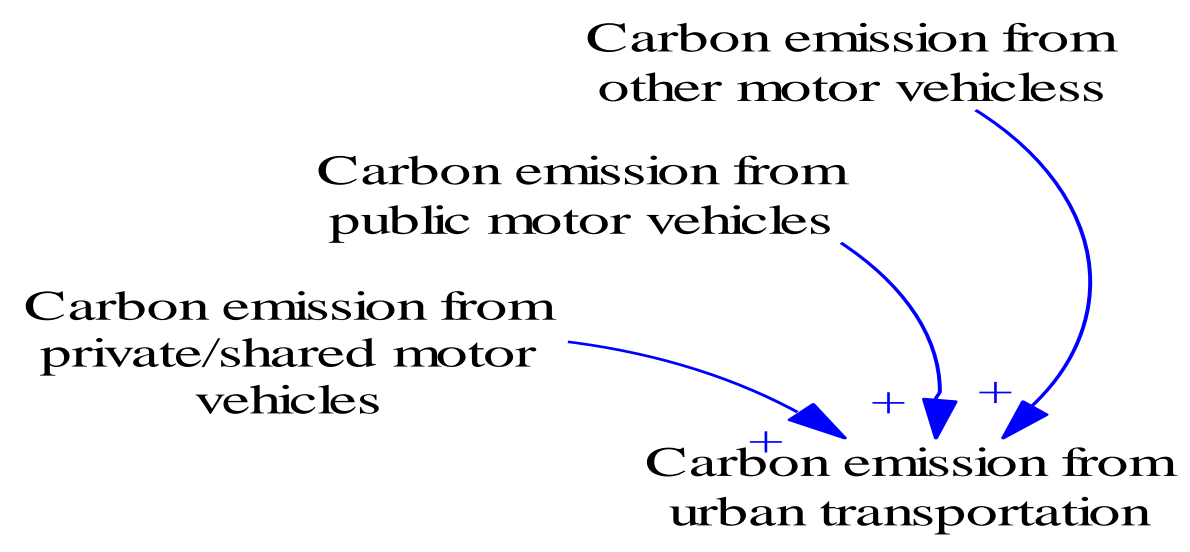

Figure 5. Carbon Emissions Sub Model.

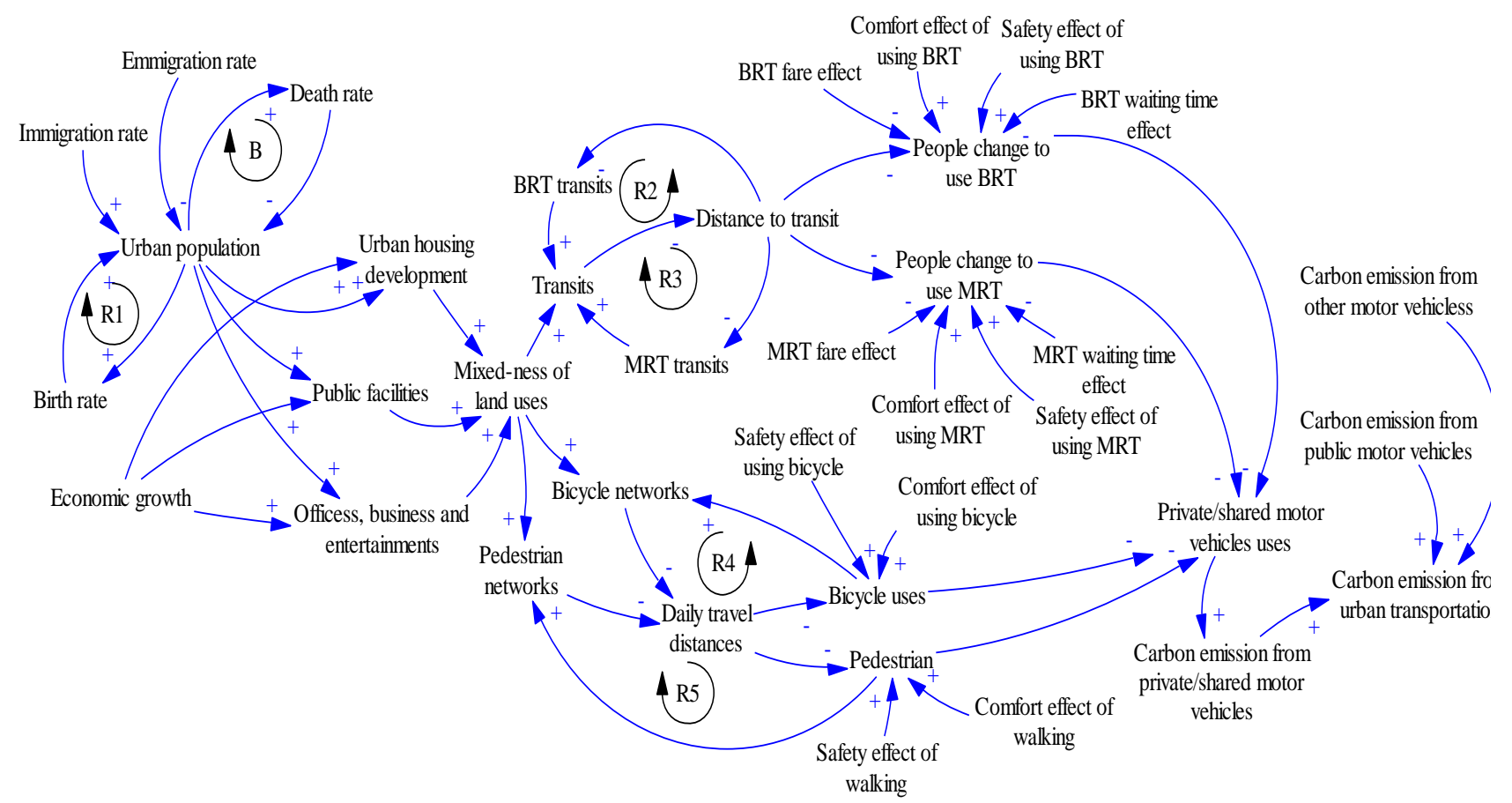

Figure 6. Causal Loop Diagram of TOD System.

because this development method is about a fast transit system, which can compete with cars on long trips, and attract more people to walk or bike on a short trip. This can lead to lower car use and denser urban structures, as a result, less fossil fuel consumption and more concentrated opportunities and services; (2) the other two dimensions are Destination accessibility and Distance to transit. Destination accessibility refers to the ease of access to travel attractions, while Distance to transit is a factor that is measured as the average of the shortest road route from a place of residence or workplace to the nearest transit node.

\section{RESULTS AND DISCUSSION}

This section presents the results of internal and external factors or variables that affect the transit-oriented development implementation in focus to reduce carbon emission by reducing the number of private/shared vehicles uses in Surabaya City. The basic pattern of the system and all the sub-model from the basic pattern is modelled and made into a causal loop diagram. The data in this study are divided into two types, namely primary data and secondary data. Primary data used as a reference in this study include data on the number of vehicles, the population of the city of Surabaya, and other official data obtained from BPS (Central Bureau of Statistics) and DISHUB (Department of Transportation). This primary data is used for system modeling purposes as a validation and comparison of the model with the actual system. The secondary data used in this study were obtained from previous studies. These data are used as material for modeling and as a research reference source. The following is the result projection of this study.

\section{A. Boundary Adequacy}

Boundary adequacies consist of internal and external variables, both significant and auxiliary, which is related to the system and affect each other in the system dynamics model built in this study. These variables are listed in Table 1 [1, 3, 4-5, 6, 13-16].

\section{B. Basic Pattern of the System}

The basic pattern of the system is used to present the big 
The $6^{\text {th }}$ International Seminar on Science and Technology (ISST) 2020

July $25^{\text {th }} 2020$, Institut Teknologi Sepuluh Nopember, Surabaya, Indonesia

picture or core structure of the system that is going to be modeled. Figure 1 shows the basic pattern of the system modelled in this study. From the variables in this basic pattern, 4 sub-models are made as steps in producing a causal loop diagram of the system. The sub-models are: (1) mixedness of land uses sub-model, (2) transits sub-model, (3) bicycle networks and pedestrian networks sub-model, and (4) carbon emissions sub-model.

\section{Mixed-ness of Land Uses Sub Model}

Figure 2 shows the generic structure of mixed land uses. As previously explained that mixed land uses have three land use criteria, namely land use criteria for urban housing, public facilities, as well as for offices, business, and entertainment, so these three things will affect the mixed-ness of land uses. The more similar the composition of land use with ideal conditions, the more effective the implementation of TOD to be built. The three land use criteria are also each affected by urban population and economic growth, where the increasing number of urban population and economic growth will further increase the development potential of each criterion. Urban population is affected by birth rate (R1), death rate (B), immigration rate, and emigration rate.

\section{D.Transits Sub Model}

Figure 3 shows the generic structure of the transits. Transits are the number sum of BRT transits (R2) and MRT transits (R3), because the use of BRT and MRT in a trip is very possible to reduce the distance to transit. The closer the distance to transit, the more likely it is for people to change from using private vehicles to using BRT and/ or MRT. In addition to distance to transit, several other factors that can be considered by people to use BRT and/ or MRT are ticket fare, comfort, safety, and waiting time. The more expensive ticket fare, the less people want to use the BRT and/ or MRT. The higher the comfort level, the more people want to use BRT and/ or MRT. The higher the level of security, the more people want to use BRT and/ or MRT. The longer the waiting time, the fewer people will want to use BRT and/ or MRT. Finally, the more people who change to using BRT and/ or MRT, the less the private/ share motor vehicles are used.

\section{E. Bicycle Networks and Pedestrian Networks Sub Model}

Figure 4 shows the generic structure of bicycle networks (R4) and pedestrian networks (R5). The construction of bicycle networks and pedestrian networks is aimed to make people want to reach places at the intended short distance by walking or cycling. The more bicycle networks and pedestrian networks, the closer the distance to the destination by walking or cycling, to increase the number of pedestrians and cyclists. In addition to the distance traveled, the safety and comfort felt by people when walking or cycling is also an important factor for people to be able to like walking and cycling. The more people like to walk or bike, the less private/share motor vehicles are used.

\section{F. Carbon Emissions Sub Model}

Figure 5 shows the generic structure of carbon emission sub-model. In this study, carbon emissions come from three sources: private/ share motor vehicles (cars and motorcycles), public motor vehicles (lyn and city buses), and other motor vehicles (light trucks, heavy trucks, etc.).

Figure 6 presents a causal loop diagram of the overall interrelationship between the variables in the system which derived from all the sub-model explained.

\section{CONCLUSION}

Conclusion of this study are as follows: (1) There are many ways to reduce carbon emissions of urban transportation, this study explains the implementation of TOD as one of the ways by focusing on how to decrease the private/ share motor vehicles uses; (2) The SD model is used to analyze the complex systems of TOD implementation with several internal and external variables which is related to the system and affect each other in the system; (3) Constructing the causal loop diagram is started with making the basic pattern of the system. This basic pattern helps to present the big picture or the core structure of the system that is going to be modeled. The variables in the basic pattern then expanded into several sub-model. At the end, these sub-models will be put together to make a complete causal loop diagram of the system; (4) The causal loop diagram was made based on the understanding and the information on the current condition of TOD implementation, it is for the model built to represent the current actual conditions; (5) The causal loop diagram produced can be used by the government and other related parties for decision making in developing strategies and policies related to TOD implementation to reduce carbon emission by reducing the private/share motor vehicles uses, and for predicting the possibility of unintended consequences in the future; (6) Further research can be done by developing several scenarios to predict which scenario are the best choice to reduce carbon emissions of urban transportation, especially in Surabaya using TOD.

\section{REFERENCES}

[1] W. Rusiawan, P. Tjiptoherijanto, E. Suganda and L. Darmajanti, "System dynamics modeling for urban economic growth and $\mathrm{CO} 2$ emission: a case study of Jakarta, Indonesia," in The 5th Sustainable Future for Human Security (SustaiN 2014), 2015.

[2] K. D. M. E. Handayeni, "TOD Best Practice: Lesson Learned for GHG Mitigation on Transportation Sector in Surabaya City, Indonesia," in Cities 2013, 2013.

[3] E. Suryani, R. A. Hendrawan, P. F. E. Adipraja, A. Wibisono and L. P. Dewi, "Urban mobility modeling to reduce traffic congestion in Surabaya: a system dynamics framework," Journal of Modelling in Management, pp. 1-33, 2020

[4] H. S. Hasibuan, T. P. Soemardi, R. Koestoer and S. Moersidik, "The Role of Transit Oriented Development in constructing urban environment sustainability, the case of Jabodetabek, Indonesia," in 4th International Conference on Sustainable Future for Human Security, SustaiN 2013, 2014.

[5] K. D. M. E. Handayeni and P. G. Ariastita, "Keberlanjutan transportasi di Kota Surabaya melalui pengembangan kawasan berbasis TOD (Transit Oriented Development)," in Tataloka Undip, 2014.

[6] Y.-H. Cheng, Y.-H. Chang and I. J. Lu, "Urban transportation energy and carbon dioxide emission reduction," Applied Energy, 2015.

[7] J. W. Schmidt and R. E. Taylor, Simulation and Analysis ofIndustrial Systems, III ed., Homewood: Richard D. Irwin, 1970.

[8] A. M. Law and W. D. Kelton, Simulation Modelling and Analysis, II ed., McGraw-Hili , 1991.

[9] O. Axella and E. Suryani, "Aplikasi Model Sistem Dinamik untuk Menganalisis Permintaan dan Ketersediaan Listrik Sektor Industri 
The $6^{\text {th }}$ International Seminar on Science and Technology (ISST) 2020

July $25^{\text {th }} 2020$, Institut Teknologi Sepuluh Nopember, Surabaya, Indonesia

(Studi Kasus : Jawa Timur)," JURNAL TEKNIK ITS, vol. 1, pp. 339 344,2012

[10] A. Firmansyah and E. Suryani, "Model Sistem Dinamik Untuk Pengembangan Smart Economy (Studi Kasus: Kota Surabaya)," JURNAL TEKNIK ITS, vol. 6, no. 2, pp. 276-281, 2017.

[11] Z. Li, Z. Han, J. Xin, X. Luo, S. Su and M. Weng, "Transit oriented development among metro station areas in Shanghai, China: Variations, typology, optimization and implications for land use planning," Land Use Policy, vol. 82, pp. 269-282, 2019.

[12] R. B. Noland, M. D. Weiner, S. DiPetrillo and A. I. Kay, "Attitudes towards transit-oriented development: Resident experiences and professional perspectives," Journal of Transport Geography, vol. 60, pp. 130-140, 2017.

[13] R. Huang, A. Grigolon, M. Madureira and M. Brussel, "Measuring transit-oriented development (TOD) network complementarity based on TOD node typology," Journal of Transport and Land Use, vol. 11 no. 1, pp. 304-324, 2018

[14] Y. J. Singh, A. Lukman, P. He, J. Flacke, M. Zuidgeest and M. v. Maarseveen, "Planning for Transit Oriented Development (TOD) using a TOD index," in Transport Research Board 94th Annual Meeting, Washington D.C., 2015.

[15] L. Meng, M. A. P. Taylor and N. Holyoak, "Stated Preference Survey Experiment Design for Transit-Oriented Development Modelling," in Australasian Transport Research Forum 2012 Proceedings, Perth, 2012.

[16] S. Xiao, H. Dong, Y. Geng, X. Tian, C. Liu and H. Li, "Policy impacts on Municipal Solid Waste management in Shanghai: A system dynamics model analysis," Journal of Cleaner Production, vol. 262, pp. $1-12,2020$. 